UDC 94(477)«19»

DOI: $10.24919 / 2519-058 x .7 .131617$

Olexandr KOZIY,

orcid.org/0000-0002-0494-3095

Ph D hab. (History), Assistant Professor of Department of the World History and Special

Historical Disciplines,

Ivan Franko Drohobych State Pedagogical University

(Ukraine, Drohobych) olkoziy@gmail.com

Oxana HORBACHYK, orcid.org/0000-0001-6671-2025

Ph D hab. (History), Assistant Professor of Department of the World History and Special

Historical Disciplines,

Ivan Franko Drohobych State Pedagogical University

(Ukraine,Drohobych) oksa7803@gmail.com

\title{
M. STAKHIV'S POLITICAL ACTIVITY IN RESEARCHES \\ BY THE REPRESENTATIVES OF UKRAINIANS ABROAD AND COMNTEMPORARY DOMESTIC HISTORIANS
}

In the article the state of the contemporary domestic scientific research of the political activity of Matviy Stakhiv, one of the most active figures of the political processes in Western Ukraine in the interwar period of the XX century, is analyzed. As is stated by the authors, his political and scientific work is specifically interesting for scientists and public circles due to its expressive displays of the interlacing of social and national aspects of the Ukrainian [independent] movement during the outlined period.

The conclusion is made that it was only in the time of Ukraine's independence that a possibility of an unbiased attempt of a comprehensive investigation of the state-construction struggles in $1918-$ 1923 became available to historians. The Ukrainian socialist movement in the interwar Poland and the scientific activity of the post-war Ukrainian emigration, however, did not lead to the appearance of any generalizing work dedicated to M. Stakhiv.

Key words: M. Stakhiv, the USRP (the Ukrainian Socialist Radical Party), the Western Ukrainian National Republic (ZUNR), the Ukrainian Galician Army (UGA), public work, emigratory period.

олександр КОзІЙ, кандидат історичних наук, доиент кафедри всесвітньої історії та спеціальних історичних дисциилін Дрогобицького державного педагогічного університету імені Івана Франка (Україна, Дрогобич) olkoziy@gmail.com

Оксана ГОРБАЧИК,

кандидат історичних наук, доцент кафедри всесвітньої історії та спеціальних історичних дисииплін Дрогобицького державного педагогічного університету імені Івана Франка (Україна, Дрогобич) oksa7803@gmail.com

\section{ГРОМАДСЬКО-ПОЛІТИЧНА ДІЯЛЬНІСТЬ М. СТАХІВА У ДОСЛІДЖЕННЯХ ПРЕДСТАВНИКІВ УКРАЇНСЬКОГО ЗАРУБІЖЖЯ ТА СУЧАСНИХ ВІТЧИЗНЯНИХ ІСТОРИКІВ}

У статті проаналізовано стан сучасного вітчизняного наукового дослідження громадсько-політичної діяльності одного з найактивніших діячів суспільно-політичних процесів Західної України у міжвоснний період ХХ сm. - Матвія Стахіва. Авторами відзначено, щзо його 
політична та наукова працяя цүікава для науковиів і громадських кіл тим, щзо виразно відображає переплетіння сочіальних та національних аспектів українського руху в окреслений період.

Зроблено висновок про те, щзо лише у період незалежності України перед істориками відкрилася можливість неупередженого всебічного дослідження державотворчих змагань 1918 - 1923 рр., украӥнського сочіалістичного руху міжвоєнної Польщі, наукової діяльності повоєнної украӥнської еміграції, щуо однак, не привело до появи узагальнюючої прачі, присвяченої М. Стахіву.

Ключові слова: М. Стахів, УСРП (Украӥнська сочіалістично-радикальна партія), Західно-Украӥнська Народна Республіка (ЗУНР), Украӥнська Галицька Армія (УГА), громадська діяльність, еміграчійний період.

The statement of the problem. In the contemporary Ukrainian historiography the political activity of a great number of Ukrainian public figures of the XIX - XX centuries presents topical directions for researches. M. Stakhiv political and scientific work $(1895-1978)$ is interesting for scientists and public circles in that it expressively displays an interlacing of social and national aspects of the Ukrainian movement during the outlined period. However, it has not been properly elucidated in the Ukrainian domestic historiography.

The article's purpose is to analyze the studies by the representatives of the Ukrainians abroad and contemporary domestic historians in which M. Stakhiv political activity is the subject of investigation.

The statement of the basic material. The achievements of the representatives of the Ukrainian scholars abroad are difficult to estimate unequivocally. An Ivano-Frankivsk researcher V. Velykochyi noticed that «after the Second World War in the Ukrainian diaspora a new period of studying of the national-political movement of the beginning of the XX century was initiated. However, despite the caused by the war deviations in the peoples' outlook, it was marked by a rigid ideological polemic coherent with attempts to place defeats and miscalculations on the opponents' shoulders» (Velykochyi, 2011: 91). At the same time, the researcher singled out the scientific produce of that time professional historians, among whom M. Stakhiv took a remarkable place. V. Velykochyi is right to notice the next: «Under a burden of their own ideological sympathies and the works of their predecessors, they had difficulties in overcoming ideological banalities, but, notwithstanding that, their works reveal inherent diligence to transfer the solutions of contradictory problems of the historical past into a plane of scientific discussions» (Velykochyi, 2011: 92).

V. Prokhoda's article «Considerations about Dr. M. Stakhiv work «Ukraine in the time of the Directory» (Prokhoda, 1967)», in which the criticism of separate concepts and thoughts expressed on the subject was presented, can serve as a vivid example of the aforementioned discussions. M. Stakhiv's research activity laid grounds for the scholarly studies of many other emigratory scientists, including I. Kedryn (Kedryn, 1986) and K. Pan'kívskyi (Pan'kívskyi, 1963), who - on the bases of their memoirs tried to recreate a difficult picture of political life of the Ukrainian society in the West Ukrainian lands in the interwar period of the XX century. The majority of the aforementioned scholars, on the one hand, turn to M. Stakhiv's researches and, on the other hand, when characterizing the political position of the USRP, repeatedly mention his name among the other party leaders. During the period under view a number of thematically more specified studies appear, as well as thorough researches containing a considerable amount of memoirs by O. Horbach (Horbach, 1949), A. Krezub (Krezub, 1966), L. Shankovskyi (Shankovskyi, 1974), etc., which acquaint the reader with the features of the UGA's (Ukrainian Galician Army's) military campaigns during 1918 - 1919, in particular, tracing part by part the way of struggle of the group «Krukenychi», which commandant was 
M. Stakhiv for a long time. The contemporary Ukrainian historiography, elucidating many particulars of M. Stakhiv's scientific and political activity, acquaints the general reader with its next four aspects: 1) his participation in operations of World War I and Ukrainian-Polish wars of 1918 - 1919; 2) his emigratory activity in Czechoslovakia; 3) his party-political work in the USRP; 4) his activity in the Ukrainian diaspora's public and scientific organizations.

The conducted analysis of the scientific works of the Ukrainian researches allow the authors to ascertain that, unfortunately, the outstanding politician's military way in the ranks of the Austro-Hungarian army and the UGA, as well as his activity in emigratory Ukrainian communities are investigated but sporadically. The major events of these issues are reconstructed on the basis of the newly revealed archival materials and memoirs of his contemporaries.

The scientific works of the first aspect partially acquaint the reader with one of the hardest periods in M. Stakhiv's life, that is, with his military fate in the front lines of the First World War and in the ranks of the UGA. Contrarily to the sufficient, as it seems, attention of the Ukrainian researchers to the problem of the Ukrainian-Polish war in 1918 - 1919, it is still hard enough to track the struggling way of separate military men of the UGA. No exception is M. Stakhiv, who - after his arrival from the Italian front in the end of 1918 joined the ranks of the Sich Riflemen. Among the Ukrainian scientists, the Lviv historian M. Lytvyn thoroughly elucidated the military actions of the Ukrainian-Polish war 1918 - 1919 (Lytvyn, 1998). Having analyzed the process of formation of the Western Ukrainian National Republic (ZUNR) military groups, in particular, the group «Krukenychi» under the command of M. Stakhiv, the researcher ascertained that «in an overwhelming majority they were formed in an organized way, and the Administrative Command of the Ukrainian Galician Army (AK UGA) already on its early stages of existence established an connection with them and formed a control system...» (Lytvyn, 1998: 141).

The contemporary researches of the second aspect (M. Stakhiv's emigratory period in Czechoslovakia) acquaint their readers with the everyday life of the Ukrainian military emigration. After the intrusion of J. Galler's army into the Polish-Ukrainian conflict, M. Stakhiv - together with the UGA's mountain units - got into the Czechoslovak camp German Yablonne. Separate pages of the life of that time interned persons among which a future leader of the USRP was, were characterized by I. Sribniak (Sribniak, 2006), V. Pryshliak (Pryshliak, 1992), M. Pavlenko (Pavlenko, 1999), and others. The latter, in particular, noticed that "the first military groups which in May, 1919 got in the territory of Czechoslovakia, were the «Mountain brigade» of ataman Cherskyi and the parts of groups «Staryi Sambir», «Hlyboka», and «Krukenychi»...» (Pavlenko, 1999: 185). Also, M. Pavlenko remarked that from the Ministry of national defence of Czechoslovakia the interned received dwelling places, provision, regimentals, and everything necessary for existence, including the salary, identical with that of Czechoslovak military men (Pavlenko, 1999: 187).

O. Dudnyk (Dudnyk, 2003) is one of few Ukrainian researchers who in details characterizes political tastes of the Ukrainian emigrant students. The scientist has singled out three factors which influenced the distribution of socialist ideas among the students of Czechoslovakia: 1) the activity of M. Drahomanov socialist circles (in the emigratory students' environment they frequently passed to communistic positions through an increase of the «communofile tendency» among the western Ukrainians); 2) in Czechoslovakia a significant amount of socialist parties existed, which were supported by the power and, personally, by president T. Masaryk who hoped that it were just socialists-democrats who would substitute 
the Bolsheviks or, at least, would come to terms with them and, then, from objects of help they would become a subject of political value; 3 ) the student milieu in Czechoslovakia was under the influence of the Ukrainian scientific emigration, then standing mostly on socialist positions (Dudnyk, 2003: 243).

The Ukrainian party-political life in the West Ukrainian lands in the interwar period of the XX century (the third aspect of scientific studies which were published in the independent Ukraine) is one of the themes which is best studied by contemporary scholars. This historiographic gap became to be a constantly and dynamically filled up in the time of Ukrainian independence. Having analyzed the development of the historical science in the 1990s, along with its tendentiousness in concern of separate problems, Ivano-Frankivsk researcher V. Velykochyi noticed that «such a situation was predetermined by a concentration of scientists' efforts on the «disclosure of falsifications» and elimination of the «blank spots» from the «actual» problems of history which «caused the greatest public resonance and interest» (Velykochyi, 2010: 373-389).

With this factor in view, the figure of M. Stakhiv, as well as the figures of many other unjustly forgotten outstanding Ukrainian politicians, has de facto «dropped out» from the scientific interests of historians. As an exception, in 1992 in Ternopil M. Stakhiv's work «Ukraine against the Bolsheviks. Sketches in the history of the aggression of Soviet Russia» has been reedited (Stakhiv, 1992). In his preface, R. Mateiko underlined an extreme topicality of M. Stakhiv's written works. The researcher emphasized this: «Many participants of the liberation struggle of the Ukrainian people who, having escaped from the totalitarian regime, were made to part with their native land, preserved and fixed [in writing] their rich recollections.... It is just with such an alloy of interesting and significant facts, truly free judgments, use of the literature inaccessible to us, and an unbiased analysis that the aforementioned doctor Matviy Stakhiv's work is valuable» (Stakhiv, 1992: 2).

In 1995 the Ukrainian public circles celebrated the 100th anniversary of M. Stakhiv's birthday, however, the date did not assist in filling up of the «blank spots» in his biography. Along the 1990s he was most frequently mentioned by scientists in the context of political processes in the interwar Poland (as shown by researches of M. Kuhutiak (Kuhutiak, 1993), S. Kulchytskyi (Kulchytskyi, 1999), Y. Hrytsak (Hrytsak, 1996), and others. This latter, as a matter of fact, considered an influence of the «young» radicals on political processes in Galicia in the beginning of the XX century and the strategy and tactics of the USRP in the Second Rzeczpospolita Polska, specified, that «the radicalization of the Ukrainian movement in the 1930s was the other side of an increasing withdrawal of the Polish regime from democracy, and an increase of judicial and police brutality» (Hrytsak, 1996: 199). Further on the number of researches of Ukrainian historians into the case of the socialists-radicals and their leaders has been constantly increasing.

On account of an insufficient level of elucidation of the lives of the well-known figures of socialist movement, M. Mishchuk's (Mishchuk, 2005) and O. Bodnar's (Bodnar, 2008) works are of a considerable interest, because they directly acquaint the readers with the peculiarities of the formation and development of this ideological trend in Western Ukraine. In particular, M. Mishchuk investigated M. Stakhiv's party-organizational work in the period of the crystallization of the USRP, his activity in the convocation of the county assemblies in Galicia and Volhynia in the late 1920s, his propaganda work during election campaigns in 1928 and 1930, and his scientific activity in the co-operative society «Self-education», etc.

O. Bodnar, considering the USRP's parliamentary activity and an extra-parliamentary work of the party members in 1928 - 1935, singled out the assemblies of which in the end of the 1920s - first half of the 1930s M. Stakhiv was one of organizers and active participants. 
The researcher noticed that those assemblies, as a rule, unanimously adopted resolutions which «approved the position of the USRP in the matters of the creation of the Ukrainian elective block», and, also, sharply criticized the position of representatives of the UNDP (Bodnar, 2008: 432).

M. Stakhiv's bitter criticism of the Soviet regime in Dnieper Ukraine and fascist tendencies of the interwar Europe did not remain unnoticed, for example, by I. Soliar (Soliar, 2011). This Lviv researcher has noticed that one of the founders of the USRP during the 1920s 1930s was the party's invariable ideologist and formed its so-called strategic and orientation line (Soliar, 2011: 268).

M. Shvahuliak has characterized the consolidation processes among the leaders of the major Ukrainian parties of Western Ukraine in the late 1930s, M. Stakhiv being one of them (Shvahuliak, 1994). The author has singled M. Stakhiv out among other figures of the Contact committee, which aspired to rally the Ukrainian political structures in face of the increasing threat of totalitarian tendencies in the Polish state. Also, M. Shvahuliak has noticed that M. Stakhiv accurately defined a strategic line of the newly formed inter-party organ: the Committee had «to show Polish political factors that the «normalization» had behind it but a small group without any significance in the Ukrainian society» (Shvahuliak, 1994: 235).

The fourth aspect of contemporary researches which concern M. Stakhiv's post-war period of life is relatively not numerous. Among the scientific studies concerning this thematic niche that of O. Shved, entitled «Stepan Vytvytskyi: his public-political activity», in which M. Stakhiv's activity in the Ukrainian National Rada is incidentally characterized, primarily deserves mentioning (Shved, 2010). The researcher has noticed that on the eve of the assembly of the Ukrainian Congress Committee in 1952 the former irreconcilable opponents, namely, M. Stakhiv and V. Mudryi, offered a resolution in which they asked the Rada to call a conference of representatives of all political groups under its initiative and supervision in order to solve the problem of participation of the Ukrainian representatives in the American Committee (Shved, 2010: 138).

The conclusions. Thus, this historiographic review certifies that the contemporary Ukrainian historiography lacks a complex scientific research which would clarify M. Stakhiv's political activity. Only in the time of Ukraine's independence, in connection with the changes of methodological paradigms and increase of the source base, the historians eventually have faced a possibility of an unbiased comprehensive investigation of the state building attempts of the 1918 - 1923, Ukrainian socialist movement in the interwar Poland, and the scientific activity of the post-war Ukrainian emigration, but, however, all that has not resulted in the appearance of the generalizing work, which would have been dedicated to the life and work of one of the USRP leaders M. Stakhiv.

The scientific and popular scientific researches by foreign scholars can be a perspective direction of a more detailed study of the theme under consideration.

\section{BIBLIOGRAPHY}

Боднар, 2008 - Боднар О. Українська соціалістично-радикальна партія: основи політичної платформи (1926 - 1939) // Україна: культурна спадщина, національна свідомість, державність. Ювілейний збірник на пошану Івана Патера. Львів: Інститут українознавства ім. І. Крип’якевича НАН України, 2008. Вип. 16. С. 430-436.

Великочий, 2010 - Великочий В. С. Австро-Угорська політика в Галичині періоду Першої світової війни: штрихи до аналізу української історіографії // Проблеми історії України XIX початку XX ст. 2010. Вип. 17. С. 373-389.

Великочий, 2011 - Великочий В. Українська історіографія про партійно-політичну систему Галичини воєнно-революційної доби: загальна характеристика // Галичина. 2011. № 12. С. 91-96. 
Горбач, 1949 - Горбач О. ЗУНР (ЗОУНР) в 1918 - 1923 рр. // Енциклопедія українознавства. Т. 1. Мюнхен; Нью-Йорк: Молоде життя, 1949. С. 527-530.

Грицак, 1996 - Я. Нарис історії України. Формування модерної нації XIX - XX століття. Київ: Генеза, 1996. 360 с.

Дудник, 2003 - Дудник О. Суспільно-політичне життя та громадянська позиція українських студентів-емігрантів у Чехословаччині у міжвоєнний період // Проблеми слов'янознавства. 2003. Вип. 53. С. 243-247.

Кедрин, 1986 - Кедрин I. У межах зацікавлення / Наукове товариство ім. Шевченка. НьюЙорк; Париж; Сидней; Торонто: [Б. в.], 1986. 523 с.

Крезуб, 1966 - Крезуб А. Нарис історії українсько-польської війни 1918 - 1919. Нью-Йорк: Око, 1966. 179 c.

Кугутяк, 1993 - Кугутяк М. Галичина: сторінки історії. Нарис суспільно-політичного руху (XIX ст. - 1939 р.). Івано-Франківськ, 1993. 200 с.

Кульчицький, 1999 - Кульчицький С. Україна між двома війнами (1921 - 1939 рр.). Київ, 1999. [Україна крізь віки]. Т. 11. 336 с.

Литвин, 1998 - Литвин М. Українсько-польська війна. 1918 - 1919. Львів, 1998. 488 с.

Міщук, 2005 - Міщук М. Національна ідея в політичних програмах та практичній діяльності Української радикальної партії (1918 - 1939 рр.) // Україна соборна: Зб. наук. статей. Київ, 2005. Вип.2. Ч. 1. С. 192-198.

Павленко, 1999 - Павленко М. Ставлення Чехословацької влади до інтернованих частин Української Галицької армії // Проблеми слов'янознавства. 1999. Вип. 50. С. 185-192.

Паньківський, 1963 - Паньківський К. У 15-ліття Української Нац. Ради // Листи до приятелів / [ред. Микола Шлемкевич]. Нью-Йорк: «Ключі», 1963. Рік ХІ. Ч. 125-126. Кн. 7-8. С. 44-46. Пришляк, 1992 - Пришляк В. Історико-просвітницька діяльність інтернованих стрільців УГА в Чехословаччині // Українська еміграція: історія і сучасність. Матеріали міжнародних наукових конференцій, присвячених 100-річчю еміграції українців до Канади. Львів, 1992. С. 301-308.

Прохода, 1967 - Прохода В. Уваги до праці д-ра М. Стахіва «Україна в добі Директорії» // Український історик. 1967. Ч.1/2 (13/14). С. 90-102.

Соляр, 2011 - Соляр I. Зовнішні орієнтації українських партій національно-державницького табору Західної України (1923-1939). Львів, 2011. 356 с.

Срібняк, 2006 - Срібняк І. Преса інтернованих частин Української Галицької Армії у Чехословаччині (1919-1921рр.) // Магістеріум (Національний університет «Києво-Могилянська Академія»). Серія «Журналістика». Київ, 2006. Вип. 22. С. 76-80.

Стахів, 1992 - Стахів М. Україна проти большевиків. Нариси з історії агресії Совєтської Росії. Тернопіль, 1992. 172 с.

Шанковський, 1974 - Шанковський Л. Українська Галицька Армія: Воєнно-історична студія. Вінніпег: Вид. Д. Микитюк, 1974. 396 с.

Швагуляк, 1994 - Швагуляк М. Маловідома сторінка політичного життя Західної України передодня Другої світової війни (3 історії Контактного Комітету. 1937 - 1939 роки) // Записки Наукового товариства імені Шевченка / [ред. Олег Купчинський]. Львів, 1994. T. CCXXVIII. С. 207-248.

Швед, 2010 - Швед О. Степан Витвицький: громадсько-політична діяльність. Львів: Астролябія, 2010. 180 с.

\section{REFERENCES}

Bodnar, 2008 - Bodnar O. Ukrainska sotsialistychno-radykalna partiia: osnovy politychnoi platformy (1926 - 1939) [The Ukrainian socialist-republican party: the bases of a political platform (1926 - 1939)] // Ukraine: cultural heritage, national consciousness, statehood. Anniversaryv collection in honour Ivan Pater. Львів: Інститут українознавства ім. I. Крип'якевича НАН України, 2008. Iss. 16. Pp. 430-436. [in Ukrainian]

Velykochyi, 2010 - Velykochyi V.S. Avstro-Uhorska polityka v Halychyni periodu Pershoi svitovoi viiny: shtrykhy do analizu ukrainskoi istoriohrafii [Austro-Hungarian politics in Galicia in the period of Word War I: the information for the analysis of Ukrainian historiography] // Problems of the history of Ukraine of the XIX - beginning of the XX cc. Iss. 17. Pp. 373-389. [in Ukrainian]

Velykochyi, 2011 - Velykochyi V. Ukrainska istoriohrafiia pro partiino-politychnu systemu Halychyny voienno-revoliutsiinoi doby: zahalna kharakterystyka [Ukrainian historiography on Galician party-political system in the war-revolutionary time: a general characteristic] // Galicia 2011. № 12. Pp. 91-96. [in Ukrainian]

Horbach, 1949-Horbach O. ZUNR (ZOUNR) v 1918-23 rr. [ZUNR in 1918-23] // Entsyklopediia ukrainoznavstva. T.1. Miunkhen; Niu-York: Molode zhyttia, 1949. Pp. 527-530. [in Ukrainian] 
Hrytsak, 1996 - Hrytsak Ya. Narys istorii Ukrainy. Formuvannia modernoi natsii XIX-XX stolittia. [Sketch in Ukraine's history. The formation of a modern nation of the XIX - XX centuries] Kyiv: Heneza, 1996. 360 p. [in Ukrainian]

Dudnyk, 2003 - Dudnyk O. Suspilno-politychne zhyttia ta hromadianska pozytsiia ukrainskykh studentiv-emihrantiv u Chekhoslovachchyni u mizhvoiennyi period [The social-political life and civic position of Ukrainian students-emigres in Czechoslovakia in the interwar period] // Problems of Slavic Studies. 2003. Iss. 53. Pp. 243-247. [in Ukrainian]

Kedryn, 1986 - Kedryn I. U mezhakh zatsikavlennia [Within the borders of interest] / Naukove tovarystvo im. Shevchenka. Niu-York; Paryzh; Sydnei; Toronto: [W. e.], 1986. 523 s. [in Ukrainian]

Krezub, 1966 - Krezub A. Narys istorii ukrainsko-polskoi viiny 1918 - 1919 [A sketch of the history of Ukrainian - Polish war of 1918 - 1919] Niu-York: Oko, 1966. 179 p. [in Ukrainian]

Kuhutiak, 1993 - Kuhutiak M. Halychyna: storinky istorii. Narys suspilno-politychnoho rukhu (XIX st. - 1939 r.). [Galicia: the pages of history. A sketch of a social-political movement (XIX c. 1939)] Ivano-Frankivsk, 1993. 200 p. [in Ukrainian]

Kulchytskyi, 1999 - Kulchytskyi S. Ukraina mizh dvoma viinamy $(1921-1939$ rr.). [Ukraine between the two wars $(1921-1939$ pp.)] Kyiv, 1999. [Ukraina kriz viky]. T. 11. 336 p.

Lytvyn, 1998 - Lytvyn M. Ukrainsko-polska viina. 1918 - 1919. [Ukrainian-Polish war of 1918 1919] Lviv, 1998. 488 p. [in Ukrainian]

Mishchuk, 2005 - Mishchuk M. Natsionalna ideia v politychnykh prohramakh ta praktychnii diialnosti Ukrainskoi radykalnoi partii (1918 - $1939 \mathrm{rr}$.) [The national idea in political programmes and the practical activity of Ukrainian radical party (1918 - 1939)] // Sovereign Ukraine: A collection of scientific articles. Київ, 2005. Iss. 2. Part 1. Pp. 192-198. [in Ukrainian]

Pavlenko, 1999 - Pavlenko M. Stavlennia Chekhoslovatskoi vlady do internovanykh chastyn Ukrainskoi Halytskoi armii [The attitude of Czechoslovak government to the interned units of Ukrainian Galician Army] // Problems of Slavic Studies. 1999. Iss. 50. Pp. 185-192. [in Ukrainian]

Pankivskyi, 1963 - Pankivskyi K. U 15-littia Ukrainskoi Nats. Rady [To the 15th anniversary of Ukrainian National Rada] // Ukrainian emigration: history and contemporaneity. Materials of international scientific conferences, dedicated to 100th anniversary of the emigration of Ukrainians to Canada. Львів, 1992. Pp. 301-308. [in Ukrainian]

Pryshliak, 1992 - Pryshliak V. Istoryko-prosvitnytska diialnist internovanykh striltsiv UHA v Chekhoslovachchyni [The historical-educational activity of the interned riflemen of UGA in Czechoslovakia]// Ukrainska emihratsiia: istoriia i suchasnist. Materialy mizhnarodnykh naukovykh konferentsii, prysviachenykh 100-richchiu emihratsii ukraintsiv do Kanady. Lviv, 1992. Pp. 301-308. [in Ukrainian]

Prokhoda, 1967 - Prokhoda V. Uvahy do pratsi d-ra M. Stakhiva «Ukraina v dobi Dyrektorii» [Remarks to Dr M. Stakhiv's work «Ukraine in the time of the Directory»] // Ukrainian historian. 1967. Part 1/2 (13/14). Pp. 90-102. [in Ukrainian]

Soliar, 2011 - Soliar I. Zovnishni oriientatsii ukrainskykh partii natsionalno-derzhavnytskoho taboru Zakhidnoi Ukrainy (1923-1939). [External orientations of Ukrainian parties of the national-state orientation of Western Ukraine (1923 - 1939)] Lviv, 2011. 356 p. [in Ukrainian]

Sribniak, 2006 - Sribniak I. Presa internovanykh chastyn Ukrainskoi Halytskoi Armii u Chekhoslovachchyni (1919 - 1921 rr.) [The press of the interned units of Ukrainian Galician Army in Czechoslovakia (1919 - 1921)] // Magisterium (the National University «Kiev Mohyla Academy». Series «Journalism». Kyiv, 2006. Vyp. 22. Pp. 76-80. [in Ukrainian]

Stakhiv, 1992 - Stakhiv M. Ukraina proty bolshevykiv. Narysy z istorii ahresii Sovietskoi Rosii. [Ukraine agaist the Bolsheviks. A skeych in the history of the aggression of Soviet Russia] Ternopil, 1992. 172 p. [in Ukrainian]

Shankovskyi, 1974 - Shankovskyi L. Ukrainska Halytska Armiia: Voienno-istorychna studiia. [Ukrainian Galician Army: a military-historical study] Vinnipeh: Vyd. D. Mykytiuk, 1974. 396 p. [in Ukrainian]

Shvahuliak, 1994 - Shvahuliak M. Malovidoma storinka politychnoho zhyttia Zakhidnoi Ukrainy peredodnia Druhoi svitovoi viiny ( $Z$ istorii Kontaktnoho Komitetu. 1937 - 1939 roky) [A little-known page of the political life of Western Ukraine on the eve of World War II (From the history of the Contact Committee. 1937-1939)] // Zapysky Naukovoho tovarystva imeni Shevchenka / [red. Oleh Kupchynskyi]. Lviv, 1994. T. CCXXVIII. Pp. 207-248. [in Ukrainian]

Shved, 2010 - Shved O. Stepan Vytvytskyi: hromadsko-politychna diialnist. [Stepan Vytvytskyi: his public-political activity] Lviv: Astroliabiia, 2010. 180 p. [in Ukrainian]

Стаття надійшла до редакиї 11.04.2018 р. 